\title{
BISNIS TOKO ONLINE
}

\author{
Decky Hendarsyah \\ Sekolah Tinggi Ilmu Ekonomi (STIE) Syariah Bengkalis \\ Jalan Poros Sungai Alam - Selat Baru, Bengkalis 28751 \\ Telp. (0766) 21550 Fax. (0766) 7007134 \\ Email:deckydb@gmail.com
}

\begin{abstract}
Intisari
Indonesia adalah negara yang jumlah populasinya besar dimana termasuk dalam salah satu negara yang terbesar dalam pemanfaatan teknologi informasi dan komunikasi. Pemerintah Indonesia melalui Kementrian Komunikasi dan Informasi berkomitmen untuk mempercepat pembangunan infrastruktur komunikasi dan Internet sampai kepelosok-pelosok daerah di seluruh Indonesia. Ini merupakan peluang besar bagi masyarakat Indonesia untuk menggunakan Internet sehingga dapat merambah keseluruh bidang kehidupan mulai dari bisnis, pendidikan, kesehatan dan lain-lain sebagai wujud kemajuan teknologi dan informasi. Masyarakat dapat menggunakan Internet mulai dari melihat informasi di surat kabar online, menjalin perteman secara online, konsultasi online, berbisnis secara online dan sebagainya. Dalam dunia bisnis sendiri sudah terjadi pergeseran dari bisnis tradisional (offline) ke bisnis online. Bisnis online banyak sekali ragam dan bentuknya, tapi dalam makalah ini lebih fokus membahas mengenai bisnis toko online. Pembahasannya mulai dari pengenalan bisnis online, alasan melakukan bisnis online, apa-apa saja bentuk-bentuk dari bisnis online, bagaimana persiapan untuk memulai bisnis toko online, bagaimana strategi pelayanan terhadap pelanggan toko online dan bagaimana cara pengelolaan bisnis toko online serta bagaimana strategi promosi toko online.

Kata Kunci: Bisnis, Online, Bisnis Online, Toko Online
\end{abstract}

\begin{abstract}
Indonesian is a large country where the population is included in one of the largest countries in the utilization of information and communication technology. The Indonesian government through the Ministry of Communications and Information committed to accelerating the development of communications infrastructure and the Internet to remote areas throughout Indonesia. This is a great opportunity for the Indonesian people to use the Internet so it can be extended to all areas of life from business, education, health and others as a form of advances in technology and information. Communities can use the Internet ranging from information in the newspaper online, make friends online, online consultation, online business and so on. In the business world, itself has been a shift from traditional business (offline) to the online business. Online business is a huge range and shape, but in this paper, focus discusses the online store. Discussion ranging from the introduction of an online business, a reason to do business online, nothing any forms of online business, how to prepare to start a business online store, how the strategy of customer service and how to shop online store business management and how to store promotion strategy online. Keywords: Business, Online, Online Business, Online Store
\end{abstract}




\section{Pendahuluan}

Perkembangan teknologi informasi dan komunikasi berkembang sedemikian pesat, sehingga merasuk kedalam sendi-sendi kehidupan masyarakat, mulai dari kalangan atas sampai kalangan bawah. Kemudian juga sudah menjadi salah satu kebutuhan yang cukup penting bagi masyarakat pada umumnya. Seiring perkembangan teknologi informasi dan komunikasi, perkembangan perangkat telepon genggam juga berkembang sedemikian pesatnya, terbukti saat ini sudah banyak beredar telepon pintar (smartphone) dan PC tablet yang terkoneksi ke internet mulai dari harga murah sampai harga yang mahal. Internet di Indonesia sudah lumayan bagus layanannya, salah satunya melalui teknologi jaringan mobile $3 G, 3.5 G$ dan $3.75 G$ yang disediakan oleh vendor-vendor penyedia Internet.

Baru-baru ini internet berkecepatan tinggi juga sudah masuk ke Indonesia, menggunakan teknologi jaringan mobile $4 G$, tapi baru dirilis di Jakarta dan kotakota besar lainnya di Indonesia. Kemungkinan besar nanti teknologi smartphone dan $P C$ tablet juga akan mengikuti perkembangan teknologi jaringan $4 G$ tersebut, sehingga akan bermunculan smartphone $4 G$. Penggunaan smartphone sendiri saat ini sudah masuk kelini terbawah masyarakat, dapat dilihat disekeliling kita, ratarata masyarakat sudah memegang smartphone dan $P C$ tablet. Dimana masyarakat menggunakan perangkat tersebut selain untuk telepon dan SMS juga untuk mengakses internet seperti browsing, facebook, twitter, black berry messenger $(B B M)$ dan lain-lain. Smartphone yang beredar di Indonesia mulai dari black berry, smartphone android, iphone dan smartphone lainnya termasuk PC tablet.

Semakin banyak masyarakat menggunakan internet, ini akan membuka peluang bagi dunia bisnis terutama bisnis online, sehingga bisnis dapat dilakukan secara online. Bagi pedagang yang biasanya berdagang di pasar, di toko dan tempat lainnya atau bagi yang baru memulai bisnis dagang dapat memanfaatkan peluang ini. Biasanya berdagang di toko terbatas dengan waktu dan tempat sambil menunggu pembeli datang. Tapi dengan berbisnis toko online dapat melebarkan sayap bisnisnya tanpa ada batas waktu dan tempat. Dalam membangun bisnis toko online ada hal-hal yang perlu diketahui dan diperhatikan supaya bisnis toko online berjalan dengan baik, maka dari itu perlu dibahas mengenai bisnis toko online.

\section{Faktor Marketing Mix ${ }^{1}$ dalam Bisnis}

Dalam menjalankan sebuah bisnis ada beberapa faktor utama yang harus diperhatikan dan dipenuhi yaitu marketing mix. Marketing mix terdiri dari $4 \mathrm{P}^{2}$ dan $3 \mathrm{P}^{3}$. Yang dimaksud dengan $4 \mathrm{P}$ adalah singkatan dari Product, Price, Place, Promotion. Sedangkan untuk 3P merupakan singkatan dari People, Process, Physical Evidence.

a) Product (produk):

Produk adalah barang atau jasa yang ditawarkan kepada masyarakat untuk mendapatkan perhatian, pembelian, atau dikonsumsi guna memenuhi kebutuhan dan keinginan masyarakat. Bukan hanya kualitas produk yang dibutuhkan konsumen, namun sistem pelayanan yang diberikan dan desain

\footnotetext{
${ }^{1}$ http://bisnisukm.com/pentingnya-marketing-mix-dalam-berbisnis.html, diakses tanggal 3 Desember 2014.

${ }^{2}$ Salim, J., 2009, Step By Step Bisnis Online, Elex Media Komputindo, Jakarta, h. 2-10

3 http://infosky.wordpress.com/2008/04/11/strategi-pemasaran-4p3p/, diakses tanggal 2 Desember 2014.
} 
produk yang menarik juga memberikan nilai lebih pada konsumen untuk membeli atau mengkonsumsi suatu produk.

Sebelum menjalankan bisnis yang harus diketahui dahulu adalah produk apa yang akan ditawarkan kepada konsumen. Produk tersebut apakah dibuat sendiri atau dibuat oleh orang lain. Jika produk dibuat oleh orang lain berarti kita hanya sekedar memasarkan produk orang lain.

Di era persaingan pemasaran pada saat ini, upaya menciptakan produk yang lebih kompetitif sangat penting sebagai strategi pemasaran. Penggunaan teknologi dan kepakaran yang tinggi sangat dibutuhkan untuk menghasilkan produk yang berkualitas, dan memiliki kelebihan yang kompetitif dikalangan persaingan, dengan memerlukan berbagai inisiatif tambahan oleh pemasar.

b) Price (harga):

Harga adalah sejumlah uang yang harus dibayar konsumen untuk mendapatkan sebuah produk atau jasa. Atau dapat juga diartikan sebagai nilai tukar untuk memperoleh keuntungan dari produk atau jasa yang dibutuhkan. Harga merupakan salah satu variable marketing mix yang bersifat fleksibel, terkadang bisa stabil dalam beberapa waktu dengan harga tertentu namun bisa juga tiba-tiba meningkat atau turun tajam disesuaikan degan kondisi permintaan pasar.

Harga dapat melambangkan kualitas produk. Tetapi, dalam realitas pemasaran fakta tersebut tidak semestinya benar untuk dijadikan asas pematokan harga yang strategis. Strategi penetapan harga menjadi penting karena faktor harga mempunyai peran dalam mempengaruhi pembeli untuk membeli dan menjadi pelanggan tetap suatu produk.

c) Place (tempat):

Place merupakan kegiatan bisnis untuk membuat produk atau jasa yang ditawarkan lebih mudah terjangkau oleh konsumen dan dapat tersedia pada sasaran pasar yang tepat. Variabel tempat juga meliputi saluran distribusi untuk menjangkau konsumen yang tersebar luas. Sehingga beberapa perusahaan membuka kantor cabang di daerah-daerah untuk memudahkan konsumennya.

Sebuah produk yang akan dijual pada suatu segmen pasar dengan harga yang tepat tentunya harus dapat dengan mudah dijangkau oleh target pasar. Bagaimanapun tepatnya produk yang dijual dan bagaimanapun tepatnya harga yang ditetapkan dengan segmen pasar, namun jika salah dalam memilih saluran distribusi, maka kemungkinan untuk gagal akan jauh lebih besar.

d) Promotion (promosi):

Promosi adalah kegiatan untuk memperkenalkan suatu produk atau jasa pada pasar sasaran, untuk membangun persepsi pelanggan mengenai produk atau jasa yang ditawarkan. Konsep promosi yang biasa digunakan antara lain advertising, public relation, sales promotion, personal selling, serta direct marketing. Tanpa promosi, pemasaran produk yang berkualitas sekalipun tidak akan menjadi aktif sehingga industri susah memperoleh tahap kompetitif yang dikehendaki di pasaran.

e) People (orang): 
People adalah semua orang yang terlibat dalam kegiatan memproduksi produk serta memberikan pelayanan produk kepada konsumen. Orang yang memproduksi dan memasarkan suatu produk juga memiliki penilaian dimata konsumen. Faktor manusia baik yang terlibat secara langsung maupun tidak langsung dalam aktivitas penyampaian produk di pasaran tidak bisa diabaikan. Karena peranannya yang menjalankan berbagai aktivitas pemasaran perlu dijadikan sebagai pertimbangan strategi pemasaran. Kemudian aspek keahlian, kemampuan dan kepakaran dari para pekerja dan pihak pengelola industri perlu juga diberi perhatian khusus sehingga dapat meningkatkan kualitas pemasaran produk.

f) Process (proses):

Proses adalah serangkaian tindakan yang diperlukan untuk memberikan produk atau jasa dengan pelayanan yang terbaik kepada konsumen. Suatu proses bisa berisi tentang metode atau prosedur yang diberlakukan untuk memperoleh produk yang dibutuhkan konsumen. Proses pelayanan yang cepat, mudah dan ramah memberikan nilai lebih konsumen terhadap suatu produk. Oleh sebab itu, dengan memasukan unsur proses kedalam strategi pemasaran akan menjadikan inisiatif yang strategis dalam suatu industri.

g) Physical Eviden (Bukti Fisik):

Physical evidence adalah perangkat-perangkat yang dibutuhkan untuk mendukung penampilan suatu produk, sehingga memperlihatkan secara langsung kualitas produk serta pelayanan yang diberikan kepada konsumen.

\section{Bisnis Online}

Bisnis online tidak berbeda jauh dengan bisnis offline. Jika di bisnis offline ada investor, maka di bisnis online juga ada investor. Bisnis offline ada strategi dalam memasarkan produk atau jasa, maka di bisnis online juga ada strateginya. Perbedaan menjalankan bisnis secara online dengan bisnis secara offline hanya terletak pada medianya saja.

Bisnis online adalah bisnis yang menggunakan media Internet sebagai pemasaran suatu produk atau jasa ${ }^{4}$. Media Internet dapat diakses melalui ponsel pintar (smartphone), tablet, komputer dan perangkat-perangkat yang terhubung ke Internet. Sedangkan produk yang dipasarkan bisa berupa barang, produk digital dan jasa. Contoh produk barang adalah seperti barang elektronik, pakaian, aksesoris, makanan dan lain-lain. Untuk produk digital seperti video, audio, software, foto, e-book dan sebagainya. Sedangkan untuk jasa dapat berupa jasa pembuatan website, pemasangan iklan, penterjemah, design grafis dan lain-lain.

Pada bisnis online dibutuhkan pihak ketiga, terutama untuk produk barang. Pihak ketiga tersebut adalah kurir untuk mengantar barang seperti JNE, TIKI, POS dan sebagainya. Untuk produk digital pelanggan bisa langsung menggunakan fasilitas download pada Internet. Sedangkan untuk produk jasa tergantung dari jenis jasa yang ditawarkan.

\footnotetext{
${ }^{4}$ Timothy, J., 2010, Membangun Bisnis Online, Elex Media Komputindo, Jakarta, h. 2.
} 


\section{Alasan Melakukan Bisnis Online ${ }^{5}$}

Untuk memulai bisnis online ada baiknya memperhatikan beberapa hal sebelum menentukan sebuah pilihan. Ada beberapa alasan mengapa orang memulai bisnis online:

a) Dapat menghabiskan waktu lebih banyak dengan keluarga atau dapat melakukan hobi yang disenangi.

b) Tidak diperlukan banyak modal untuk menjalan bisnis. Lebih banyak waktu dan dana yang dihemat.

c) Bekerja untuk diri sendiri.

d) Tidak ada jam kerja yang rutin dan monoton serta dapat memanfaatkan waktu luang untuk menjalankannya sambil tetap melakukan pekerjaan utama atau bisnis lainnya.

e) Mempunyai laptop atau smartphone, sehingga dapat menambah produktivitas bisnis. Tidak diperlukan ruang kantor atau ruang khusus untuk menjalankan bisnis dan dapat dilakukan dimana saja.

f) Tidak perlu pergi ke bank untuk meminjam dana yang besar untuk memulai bisnis online.

g) Semua komisi dan pengeluaran bisa diatur sendiri. Pendapatan yang didapatkan bisa melebihi pekerjaan utama atau bisnis lainnya.

h) Bisnis tetap dapat berjalan 24 jam nonstop melalui internet.

\section{Jenis-Jenis Bisnis Online 6}

Dunia internet adalah dunia maya, sehingga siapapun bisa melakukan apa saja di internet. Banyak di antaranya adalah untuk mencari penghasilan, baik dengan cara-cara legal maupun cara ilegal dengan trik-trik tertentu. Bisnis online terdapat 2 macam yaitu bisnis online nyata dan bisnis online samar.

a) Bisnis online nyata:

Bisnis online nyata maksudnya adalah bisnis internet yang dilakukan secara legal menurut hukum, nyata menurut keabsahannya, jelas dan tidak menipu dengan apa yang dibisniskan.

Contoh bisnis online nyata:

- Lelang online, seperti: www.onsale.com, www.ebay.com, www.alibaba.com dan lain-lain.

- Toko online, seperti: www.bhineka.com, www.lazada.co.id, www.zalora.co.id, www.tokopedia.com dan lain-lain.

- Home industry online, seperti: www.limbahplastik.com, www.bisnispekalongan.com, www.homeindustri.net dan lain-lain.

- Menjual informasi (buku atau e-book), seperti: www.amazon.com, www.gramediaonline.com, www.ekuator.com, www.andipublisher.com dan lain-lain

- Agency online, seperti: www.traveloka.co.id, www.wego.co.id dan lainlain.

- Jasa online, seperti: jasa design grafis, jasa pembuatan website, jasa konsultan dan lain-lain

5 http://ekonomi.kompasiana.com/wirausaha/2012/06/11/10-alasan-mengapa-anda-harusmemulai-bisnis-online-468892.html diakses tanggal 5 Desember 2014.

${ }^{6}$ Hakim, M., 2010, Langkah Awal Memulai Bisnis Online, MediaKom, Yogyakarta, h.10. 
- Periklanan online, seperti: www.berniaga.com, www.olx.co.id dan lainlain.

b) Bisnis online samar

Dalam dunia bisnis di internet banyak ditemukan bisnis-bisnis yang samar. Samar yang dimaksud adalah situs bisnis yang tidak jelas dengan apa yang dibisniskannya atau sesuatu yang dibisniskan akan tetapi tidak jelas bentuk dan wujudnya. Sehingga hasil dari bisnis tidaklah jelas dan masih perlu tidak lanjut.

Contoh bisnis online samar:

- Arisan Berantai

- Surat atau Email Berantai

- Reseller samar

- Money Game

\section{Persiapan Bisnis Toko Online}

Bisnis toko online pada prinsipnya sama dengan bisnis toko tradisional (offline). Sebelum memulai melakukan bisnis toko online ada beberapa hal yang harus dipersiapkan, yaitu:

a) Tentukan produk yang akan dibisniskan. Produk bisa diproduksi sendiri atau diambil dari produk orang lain (supplier) atau disebut juga dengan reseller.

b) Tentukan target pasar yang akan dimasuki. Target pasar atau segmen pasar sangat penting karena produk yang akan dijual untuk kalangan mana, jadi harus ditentukan. Misalnya produk yang diperuntukan untuk mahasiswa berarti harus dicari kenalan mahasiswa. Atau produk kecantikan berarti harus dicari kenalan perempuan dan sebagainya.

c) Tentukan kisaran harga dari produk yang akan dijual.

d) Siapkan modal awal dan biaya operasional awal.

e) Tentukan nama domain atau nama website dari toko online, sebaiknya nama yang mudah diingat oleh pelanggan seperti lazada.co.id, bhineka.com, zalora.co.id, tokopedia.com, amazon.com dan lain-lain. Nama domain untuk bisnis online bisa menggunakan .com, .co, .biz atau .co.id (.id domain komersial untuk Indonesia). Untuk pengurusan domain .co.id biasanya mempunyai syarat yang lebih banyak dari pada .com, .co dan .biz seperti berikut: softcopy fotocopy KTP/SIM/Paspor, fotocopy SIUP/TDP/NPWP/Akta Notaris, kepemilikan merek (bila ada), surat keterangan keterkaitan antara nama domain dengan nama perusahaan jika nama domain berbeda dengan nama perusahaan yang ada di SIUP. Sedangkan untuk pengurusan nama domain .com, .co dan .biz hanya menggunakan softcopy fotocopy KTP/SIM/Paspor untuk penyedia domain tertentu, tetapi ada juga penyedia domain tidak meminta softcopy fotocopy KTP/SIM/Paspor.

f) Pilih hosting yang profesional dan terpercaya, biasanya untuk domain dan hosting dapat diurus pada satu tempat penyedia layanan hosting. Hosting adalah tempat untuk meletakan file-file atau data-data website dari toko online yang akan di onlinekan. Yang perlu diperhatikan dalam hosting adalah berapa besar kapasitas harddisk yang dibutuhkan untuk menampung file-file dari website toko online. Kemudian berapa besar 
bandwidth yang dibutuhkan dalam satu bulan, jika pelanggan yang akan mengakses website diperkirakan banyak sebaiknya bandwidth dipilih dalam ukuran besar, karena jika kapasitas bandwidth kecil kemudian pelanggan yang mengakses website banyak dan melebihi kuota bandwidth maka website akan susah diakses dan tidak bisa dibuka oleh pelanggan.

g) Pilihlah vendor pembuat website jika tidak bisa membuat website dan masalah nama domain dan hosting bisa dikonsultasikan dengan pembuat website.

h) Persiapkan personal kontak toko online seperti telepon, email, yahoo messenger, google talk, line, wechat, whatapps, pin BB dan sebagainya yang bisa dihubungi.

i) Daftarkan toko online pada media sosial sebagai media promosi seperti di facebook, BBM dan twitter.

j) Perangkat komputer dan smartphone yang mempunyai koneksi ke internet.

k) Sediakan nomor rekening untuk kegiatan transaksi pembayaran produk, sebaiknya gunakan lebih dari satu rekening bank misalnya rekening bank BCA, Mandiri, BNI, BRI dan lain-lain, supaya memudahkan pelanggan untuk memilih rekening sesuai dengan rekening yang dipunyai pelanggan, karena jika berbeda bank maka pelanggan akan dibebani dengan biaya transfer. Kemudian sebaiknya semua rekening tersebut harus didaftarkan internet banking dan SMS bankingnya, supaya mudah memantau transaksi pembayaran dari pelanggan.

\section{Pengelolaan Toko Online}

Pengelolaan toko online merupakan sekaligus kegiatan pemasaran toko online dapat dilakukan dengan beberapa cara yaitu dengan menggunakan Black Berry Messenger (BBM), Facebook dan Website:

a) Black Berry Messenger (BBM)

Pengelolaan toko online dengan menggunakan $B B M$, pertama kali yang harus dilengkapi adalah salah satunya perangkat smartphone baik black berry, PC tablet, smartphone android ataupun iphone yang terkoneksi ke internet. Untuk smartphone black berry aplikasi BBM sudah terpasang diperangkat tersebut. Sedangkan untuk smartphone android dan iphone, aplikasi $B B M$ harus didownload dulu di application store masing-masing smartphone.

Setelah aplikasi $B B M$ terpasang di perangkat smartphone, daftarkan diri dengan menggunakan email, password dan data-data pribadi. Setelah mendaftarkan diri maka akan mendapatkan sebuah pin yang nantinya digunakan sebagai penghubung dengan pengguna $B B M$ lainnya. Kemudian langkah selanjutnya adalah mencari teman sebanyak-banyaknya sebagai target pasar yang akan dimasuki.

Untuk mencari teman bisa langsung minta pin BBM kekenalan atau teman ataupun bisa memberikan pin yang dipunyai kepada kenalan. Setelah mendapatkan teman yang lumayan banyak, buatlah sebuah group di $B B M$ dan ajak teman-teman untuk bergabung digroup tersebut. Kemudian untuk pemasaran atau informasi produk-produk dari toko bisa menggunakan 
fasilitas status $B B M$, gambar status $B B M$, obrolan, broadcast obrolan ataupun melalui group.

- Status $B B M$ dapat digunakan untuk menginformasikan harga terbaru dari barang ataupun informasi mengenai adanya discount untuk barang-barang tertentu.

- Gambar status $B B M$ dapat digunakan untuk memperlihatkan produkproduk atau koleksi terbaru. Untuk gambar status $B B M$ sebaiknya sering diganti sehingga bisa menarik perhatian dari teman-teman yang ada di $B B M$.

- Obrolan dapat digunakan jika ingin menawarkan produk langsung ke satu atau beberapa teman sekaligus. Kemudian obrolan juga dapat digunakan untuk proses tawar menawar, jual beli, metode pembayaran produk, informasi jasa pengiriman, konfirmasi pembayaran dari pelanggan dan pemberitahuan produk sudah dikirim. Fasilitas obrolan ini dapat digantikan dengan menggunakan SMS jika jaringan internet bermasalah.

- Broadcast obrolan dapat digunakan untuk memberikan informasi penting ke teman-teman $B B M$ seperti ada discount atau produk baru. Tapi untuk broadcast obrolan jangan terlalu sering digunakan karena akan membuat teman-teman $B B M$ akan menjadi bosan dan merasa terganggu.

- Group dapat digunakan untuk memberikan informasi penting ke teman-teman yang bergabung di dalam group seperti ada potongan harga, harga promo atau produk-produk baru. Pada group boleh memberikan informasi-informasi terbaru dengan frekuensi lebih sering, karena yang bergabung ke group biasanya orang-orang yang ingin tahu tentang produk-produk apa saja yang ditawarkan. Kemudian di group ini juga dapat dimasukan foto dari koleksi produk yang dimiliki. Sehingga komunitas yang ada didalam group bisa melihat produk-produk yang tersedia.

\section{b) Facebook}

Pengelolaan toko online dengan menggunakan facebook dibutuhkan minimal salah satu perangkat keras seperti komputer, laptop, PC tablet atau smartphone yang mempunyai koneksi ke internet. Facebook bisa diakses melalui web browser yang ada pada komputer maupun smartphone seperti google chrome, mozila firefox, internet explorer, safari dan lainlain melalui alamat website www.facebook.com. Kemudian facebook juga bisa diakses melalui aplikasi yang tersedia pada $P C$ tablet atau smartphone.

Untuk mendaftar sebagai pengguna facebook bisa masuk ke website www.facebook.com melalui browser pada $P C$ tablet atau smartphone, kemudian klik tombol buat akun baru, setelah itu masukan nama lengkap (atau bisa menggunakan nama toko online), email atau telepon, jenis kelamin, tanggal lahir dan password atau kata sandi.

Sedangkan mendaftar menjadi pengguna facebook melalui komputer atau laptop setelah masuk ke website www.facebook.com maka langsung isikan nama depan dan nama belakang (bisa menggunakan nama toko online), email atau nomor ponsel, ulang masukan email atau nomor ponsel, kata 
sandi baru, tanggal lahir dan jenis kelamin dan klik tombol mendaftar. Setelah itu ikuti proses selanjutnya memasukan kode yang dikirim melalui email atau nomor ponsel yang didaftarkan. Setelah terdaftar sebagai pengguna facebook, cari teman sebanyak mungkin sesuai dengan segmen pasar atau target pasar toko online. Pada facebook untuk pemasaran produk-produk dapat melalui fasilitas status, album foto, pesan, group.

- Status facebook dapat digunakan untuk menginformasikan harga terbaru dari produk ataupun informasi mengenai adanya potongan harga untuk produk-produk tertentu. Kemudian juga dapat digunakan untuk menampilkan foto produk-produk terbaru sekaligus sambil menyebutkan atau menandai nama-nama teman yang dirasa tertarik untuk produk terbaru tersebut. Status facebook ini juga bisa digunakan untuk mempromosikan website toko online dengan cara mengetik atau mengcopy-paste link atau alamat dari website toko online yang ada.

- Album foto bisa digunakan untuk menampung foto produk-produk yang dijual ditoko online. Sebaiknya foto dari produk-produk diberi label kode yang unik, sehingga ketika ada teman facebook yang tertarik dengan suatu produk, tinggal menanyakan informasi dengan menyebutkan kode produk tersebut.

- Pesan sebaiknya digunakan untuk melayani pertanyaan dari temanteman facebook, jangan digunakan untuk promosi produk, karena akan membuat teman facebook terganggu. Kemudian pesan juga dapat digunakan untuk proses tawar menawar, jual beli, metode pembayaran produk, informasi jasa pengiriman, konfirmasi pembayaran dari pelanggan dan pemberitahuan produk sudah dikirim. Fasilitas pesan ini dapat digantikan dengan menggunakan SMS jika jaringan internet bermasalah.

- Group dapat digunakan untuk memberikan informasi penting ke teman-teman yang bergabung di dalam group, sama seperti halnya membuat status dan album foto. Pada group boleh memberikan informasi-informasi terbaru dengan frekuensi lebih sering, karena yang bergabung ke group biasanya orang-orang yang ingin tahu tentang produk-produk apa saja yang ditawarkan pada toko online.

c) Website

Pengelolaan toko online dengan menggunakan website diperlukan seperangkat komputer atau laptop yang mempunyai koneksi ke internet. Kemudian juga dapat menggunakan smartphone yang terkoneksi ke internet. Sebelum mengelola website yang harus diperhatikan dan ditetapkan adalah mengenai nama domain dan hosting dari toko online serta penyedia layanan hosting yang profesional dan terpercaya seperti yang telah dijelaskan sebelumnya.

Setelah nama domain dan hosting sudah tersedia yang harus disiapkan adalah halaman website itu sendiri. Halaman website bisa dikerjakan sendiri jika mempunyai kemampuan untuk memprogram bahasa pemrograman $P H P$ dan $M y S Q L$ atau bahasa pemrograman lainnya. Tetapi jika tidak ada kemampuan untuk membuat halaman website, maka dapat dicari vendor atau pihak lain untuk mengerjakan halaman website yang diinginkan. Halaman website juga dapat dibeli ke pihak lain yang menjual 
website toko online, tetapi untuk website yang di beli biasanya sudah standard dan tidak bisa dirubah sesuai keinginan kecuali source code website diberikan. Kemudian yang perlu diperhatikan terkait dengan halaman website toko online adalah:

- Harus mengetahui host, username dan password dari hosting dan ftp dari website. Ini biasanya diberikan oleh penyedia layanan hosting. Sehingga halaman website toko online dapat diperbaharui setiap saat.

- Tersedia halaman admin untuk mengelola website, dimana fungsinya adalah untuk mengatur user, isi dari halaman website, melihat pesanan atau pembelian dari pelanggan, membuat laporan produk, laporan penjualan dan lain-lain. Ini harus tersedia jika website dibeli atau dibuat oleh pihak lain.

- Tersedia fitur halaman untuk pelanggan atau member. Maksudnya pelanggan dapat mendaftarkan diri sebagai anggota (member) pada website toko online, sehingga pelanggan bisa masuk (login) untuk melihat produk-produk yang disukai kemudian memilih dan langsung diklik setelah itu masuk ke keranjang pembelian. Di dalam keranjang pembelian pelanggan bisa melihat total harga dari produk yang dipilih dan juga bisa membatalkan produk yang dipilih. Ketika pelanggan sudah selesai memilih produk, tinggal membayar sesuai dengan total harga yang ditampilkan di halaman website dengan metode pembayaran yang telah ditentukan dan diberikan nomor transaksi pembelian sekaligus sebaiknya informasi tersebut juga dikirim ke email pelanggan. Selain itu jika pelanggan tidak mau mendaftarkan diri tetapi hanya ingin langsung membeli maka harus disediakan juga fitur halaman untuk hal tersebut, sehingga pelanggan bisa memilih produk yang disukai dan diklik langsung masuk ke keranjang pembelian dan sebaiknya pelanggan harus memasukan email jika setuju untuk membeli sehingga informasi transaksi terkirim ke email pelanggan, dimana didalam informasi transaksi tersebut terdapat nomor transaksi kemudian baru melakukan pembayaran. Kemudian dalam informasi transaksi yang dikirim ke email sebaiknya juga memberikan informasi berapa berat barang dan besaran ongkos kirim serta nomor rekening bank pembayaran.

- Tersedia fitur halaman untuk konfirmasi pembayaran dari pelanggan. Sehingga ketika pelanggan telah membayar produk yang dipesan bisa melakukan konfirmasi secepatnya melalui halaman konfirmasi menggunakan nomor transaksi yang telah dikirim melaui email atau tercantum dihalaman member.

- Terdapat kontak person dan tempat konsultasi seperti nomor telepon, nomor SMS, yahoo messenger untuk chating, pin BBM, whatapps, line, dan lain-lain. Kontak person sebaiknya diberi jadwal layanan misalnya melayani selama 24 jam, Senin sampai Sabtu pukul 07.00 WIB sampai 21.00 WIB dan sebagainya tergantung ketersedian waktu yang dimiliki oleh pemilik toko online. Tujuannya supaya pelanggan dapat menghubungi kontak person sesuai dengan jadwal telah diberikan.

- Tidak menampilkan nomor rekening di halaman website, karena bisa disalah gunakan oleh pihak lain. Nomor rekening sebaiknya 
diinformasikan dalam informasi transaksi ketika pelanggan setuju untuk melakukan pembelian.

- Isi halaman website toko online terutama mengenai produk sebaiknya selalu diupdate minimal sekali dalam satu minggu sehingga dapat menarik minat dari pelanggan karena terdapat produk-produk baru. Kemudian dengan sering mengupdate website juga dapat menghilangkan presepsi pelanggan bahwa toko online bukan toko online tipu-tipuan.

- Tersedia fitur halaman produk-produk terbaru.

- Terdapat potongan-potongan harga dimana potongan harga dapat diberikan pada waktu hari-hari besar tertentu sehingga menarik minat pelanggan untuk membeli.

- Tersedia fitur halaman yang menampilkan produk terlaris dan produk yang sering dilihat oleh pelanggan. Sebab secara psikologis para pelanggan akan tertarik dengan produk-produk yang banyak dilihat atau diminati oleh pelanggan lainnya.

- Tersedia fitur halaman untuk komplain barang misal barang rusak, barang tidak sampai ke alamat dan lain-lain.

- Tersedianya sertifikasi keamanan website.

Fitur-fitur website di atas dapat digunakan semuanya jika toko online akan dikelola secara besar-besaran atau toko online yang sedang berkembang, tapi bagi toko online kecil-kecilan bisa memilih fitur-fitur sesuai dengan kebutuhan.

Pengelolaan toko online di atas dapat dipilih salah satu atau dijalankan semuanya. Jika ingin mengelola toko online hanya melalui BBM atau facebook, ini tidak memerlukan dana yang besar hanya biaya pulsa untuk smartphone. Sedangkan mengelola toko online menggunakan website, ini akan memerlukan dana, tergantung dari kebutuhan dan fasilitas website yang dibangun.

\section{Strategi Pelayanan Pelanggan Toko Online}

Dalam melakukan pelayanan terhadap pelanggan toko online terdapat beberapa strategi yang dilakukan agar pelanggan tetap setia terhadap toko online yang dijalankan. Adapun strateginya adalah sebagai berikut:

a) Menjaga kesederhanaan dalam menampilkan informasi produk.

b) Menyediakan katalog produk serta deskripsi produk sedetail-detailnya.

c) Memberikan kemudahan dalam cara pembelian.

d) Menunjukan sertifikasi keamanan website yang bagus.

e) Menjaga privasi atau informasi pribadi yang diberikan pelanggan.

f) Menawarkan harga terendah kepada pelanggan.

g) Memudahkan akses pelanggan melalui kontak person yang jelas.

h) Memberikan nomor bebas pulsa.

i) Memberikan ketepatan waktu dalam pengiriman barang.

j) Mengontrol infrastruktur toko online seperti perawatan server ataupun website.

k) Memberikan respon cepat terhadap pertanyaan ataupun keluhan dari pelanggan.

1) Menggunakan penjawab otomatis. 
m) Melakukan konfirmasi mulai dari packing sampai pengiriman barang.

n) Memberikan harga pengiriman termurah.

o) Menyertakan garansi kepuasan pelanggan.

\section{Strategi Promosi Website Toko Online}

Website merupakan salah satu media untuk promosi produk toko online, akan tetapi alamat website juga harus dipromosikan, karena orang tidak akan tahu alamat suatu website jika tidak dikenalkan. Mempromosikan website dapat dilakukan dengan beberapa cara mulai dari yang gratis sampai yang berbayar yaitu:

a) Menampilkan link alamat website dan mengajak teman-teman untuk mengunjungi website tersebut di status atau group $B B M$ dengan bahasa yang tidak memaksa dan santun.

b) Menampilkan link alamat website dan mengajak teman-teman untuk mengunjungi website tersebut di status atau group facebook dengan bahasa yang tidak memaksa dan santun.

c) Menampilkan alamat website melalui gambar di BBM dan facebook.

d) Menyisipkan kode program tertentu di halaman website agar bisa terbaca oleh mesin pencari google dan yahoo. Tetapi sebelumnya harus mendaftarkan alamat website di google dan yahoo. Setelah itu akan diberikan kode program yang harus dimasukan dalam halaman website.

e) Menampilkan keyword didalam program halaman website supaya dapat terbaca oleh mesin pencari di internet.

f) Membuat link-link alamat website di blog-blog yang dikunjungi, tapi harus seizin dari pemilik blog.

g) Mengiklankan alamat website melalui google, yahoo ataupun koran-koran online baik berupa foto maupun teks, tapi harus menyediakan dana untuk iklan tersebut.

h) Mengiklankan website di media televisi, ini menyediakan dana yang cukup besar.

\section{Keuntungan dan Kekurangan Bisnis Toko Online}

Dalam melakukan bisnis toko online ada beberapa keuntungan yaitu sebagai berikut:

a) Tidak perlu menyewa toko atau tempat khusus jika tidak ingin berdagang offline seperti berdagang dipasar, diruko ataupun dimall.

b) Toko online bisa buka 24 jam tanpa perlu dijaga, sehingga kapanpun pelanggan dapat melihat produk-produk yang tersedia.

c) Produk-produk dapat dilihat atau diakses oleh pelanggan dari seluruh dunia yang terkoneksi dengan internet.

d) Toko online dapat dikelola dimana saja selama terdapat koneksi internet.

Dalam melakukan bisnis toko online juga terdapat kekurangan yaitu sebagai berikut:

a) Koneksi internet yang kurang bagus akan mengganggu jalannya toko online.

b) Apabila toko online menggunakan website maka pengelolanya harus memiliki pengetahuan tentang pemrograman web. Tapi bagi pemilik 
sekaligus menjadi pengelola toko online yang tidak punya pengetahuan tentang pemrograman web maka ini merupakan suatu hal yang sulit, mungkin dapat dicari orang lain untuk mengelolanya tapi akan membutuhkan dana tambahan untuk menggaji orang tersebut.

\section{Penutup}

Sebagai penutup dapat ditarik kesimpulan dan saran dari makalah ini. Adapun kesimpulan dan saran yang dapat diberikan dari makalah ini adalah sebagai berikut:

a) Dalam menjalankan bisnis toko online tidak jauh beda dengan menjalankan bisnis toko tradisional (offline) yang membedakan hanya waktu, tempat dan medianya saja.

b) Dalam menjalankan bisnis toko online harus disesuaikan dengan kemampuan modal. Jika modal terbatas bisnis maka toko online dapat dikelola melalui fasilitas $B B M$ atau facebook saja karena $B B M$ atau facebook merupakan fasilitas gratis hanya bermodalkan pulsa atau biaya internet. Apabila modal yang dimiliki cukup maka toko online dapat di kelola menggunakan fasilitas $B B M$, facebook dan website sederhana. Tetapi jika mempunyai modal yang banyak maka dapat memakai fasilitas BBM, facebook dan website dengan fitur lengkap.

c) Dalam menjalankan bisnis toko online koneksi internet merupakan hal yang paling utama, jadi koneksi internet harus dipastikan berjalan dengan baik.

d) Dalam menjalankan bisnis toko online kepuasan dari pelanggan harus diperhatikan, karena pelanggan yang merasa puas dengan layanan toko online maka dia akan kembali lagi untuk membeli produk lain dari toko online tersebut.

e) Selain dari $B B M$ dan facebook sebagai fasilitas gratis untuk menjalankan bisnis toko online, bisa menggunakan media sosial lainnya seperti twitter, google,+ ts $\bar{u}$, path dan lain sebagainya. 


\section{DAFTAR PUSTAKA}

Enterprise, J., 2009, 63 Jenis Usaha Bisnis Online Sambilan Buat Siapapun!, Elex Media Komputindo, Jakarta.

Hakim, M., 2010, Langkah Awal Memulai Bisnis Online, MediaKom, Yogyakarta.

Igen, R., 2010, Strategi Sukses Berjualan Online, Mediakita, Jakarta.

Oviliani Yenty Yuliana, 2000, "Penggunaan Teknologi Internet Dalam Bisnis", Jurnal Akuntansi \& Keuangan Vol. 2, No. 1, Mei 2000: 36 - 52, Universitas Kristen Petra, Surabaya.

Priyatno, D., 2009, Panduan Mudah Bisnis Online, MediaKom, Yogyakarta.

Salim, J., 2010, Online Entrepreneur, Elex Media Komputer, Jakarta.

Salim, J., 2009, Step By Step Bisnis Online, Elex Media Komputindo, Jakarta.

Timothy, J., 2010, Membangun Bisnis Online, Elex Media Komputindo, Jakarta.

Widoatmodjo, S., 2005, New Business Model, Elex Media Komputindo, Jakarta.

http://infosky.wordpress.com/2008/04/11/strategi-pemasaran-4p3p/, diakses tanggal 2 Desember 2014.

http://bisnisukm.com/pentingnya-marketing-mix-dalam-berbisnis.html, diakses tanggal 3 Desember 2014

http://ekonomi.kompasiana.com/wirausaha/2012/06/11/10-alasan-mengapa-andaharus-memulai-bisnis-online-468892.html, diakses tanggal 5 Desember 2014 